\title{
Three bubbles and a panic: An explanatory review of recent food commodity price events
}

\author{
Jenifer Piesse ${ }^{\mathrm{a}, \mathrm{b}}$, Colin Thirtle $\mathrm{c}^{\mathrm{c}, \mathrm{d}, *}$ \\ a Department of Management, King's College London, Stamford Street, London SE1 9HN, United Kingdom \\ ${ }^{\mathrm{b}}$ University of Stellenbosch, Republic of South Africa \\ ${ }^{c}$ Centre for Environmental Policy, Imperial College London, Exhibition Road, London SW7 2AZ, United Kingdom \\ ${ }^{\mathrm{d}}$ Department of Agricultural Economics, Extension and Rural Development, University of Pretoria, Pretoria, Republic of South Africa
}

\section{A R T I C L E I N F O}

Article history:

Received 18 December 2008

Received in revised form 7 January 2009

Accepted 7 January 2009

Available online $\mathrm{xxxx}$

Keywords:

Food prices

Speculation

Supply

Demand

\begin{abstract}
A B S T R A C T
This paper is a summary of the behaviour of food commodity prices in 2007-2008 and a review of the causes of the price increases, extracted from a report to the Chief Scientific Advisor to Her Majesty's Government [Thirtle, C., Piesse, J., 2008. An Explanatory Review of the World Food Commodity Price Events of 2007-2008. A Report to the Chief Scientific Advisor. Department for Innovation, Universities and Skills, London]. The historical background shows that the price spike was much less severe than in the 1970s. The conventional wisdom that prices of the main food commodities were falling prior to 2006 is questioned. Most ceased falling and were quite stable from the 1980s. The paper separates the causes of the spike from the underlying changes driving the long run trends. The literature on the causes of the spike is critically reviewed and summarised. There is a reasonably broad consensus on most of the causes, but much less on the impact of the depreciation of the US Dollar. There are also concluding speculations on the future.
\end{abstract}

(c) 2009 Elsevier Ltd. All rights reserved.

\section{The food commodity price rises of 2007-2008 in historical perspective}

The suddenness and extent of the increases in world commodity prices in 2007-2008 took the world by surprise, even the institutions that monitor the world food situation. However, the notion of soaring food prices is based on nominal prices. Wheat prices reached a peak in March 2008 and in nominal terms were 50\% higher than in the severe shortage of 1973 . However, if the nominal prices are deflated to put all the observations in constant 2007 US \$, the 2008 peak is at less than 50\% of the 1973 level. Putting prices in constant terms at a base year price is standard practice, without which comparisons over time are meaningless, as economic welfare depends on real consumption. The real prices take account of how much lower incomes were in 1973.

Fig. 1 shows the series in real terms, or constant US \$, which makes it clear that the current price spikes are more like the blips in the 1980s and 1990s than the 1970s crisis. None of these four commodities is anywhere near the 1974 peaks (1973 in the case of soybeans). As of April 2008, wheat was at 55\% of the 1974 peak, maize at $41 \%$, rice at $24 \%$ and soybeans at $39 \%$. This illustrates how powerful the downward trend has been. In real terms, food is far cheaper than it was a generation ago.

\footnotetext{
* Corresponding author. Address: Centre for Environmental Policy, Imperial College London, Exhibition Road, London SW7 2AZ, United Kingdom.

E-mail address: c.thirtle@imperial.ac.uk (C. Thirtle).
}

However, these data do not show a steady decline in grain prices. Although the change was not noted by most observers before the 2008 price spike, FAO are now pointing out that the long term decline in grain prices was over long before $2006 .{ }^{1}$ A more careful look at Fig. 1 suggests that wheat and maize prices seem to be fluctuating around a fairly constant trend from the mid to late 1980s. Estimation of the growth rates confirms this. ${ }^{2}$ The first row of Table 1 confirms the visual impression, as although the growth rate of the wheat price was negative, it is less than half a percent per annum and the $t$ statistic shows that this result is not significantly different from zero. Thus, it is fair to claim that wheat prices ceased declining as much as 20 years ago. Maize seems to follow wheat really closely and thus the result, in the next row, is similar, but not as strong. For $1987-2006$ the growth rate is $-0.80 \%$ and the $t$ statistic is -1.56 , which again says that the trend is not significantly different from zero at the 5\% confidence level. Adding 2007, in the next row, which is permissible in that the 2007 price was still lower than some previous years, makes this more emphatic. The growth rate falls to $-0.60 \%$ and the $t$ statistic to -1.16 , which is very similar to the result for wheat. Put another way, the maize price was below the 1987 level only in one year, which was 2005. This is not evidence of a declining trend.

\footnotetext{
1 This position was clearly stated by Alexander Sarris at a conference at Wye College (Sarris, 2008).

2 The growth rates are estimated by regressing the logarithm of TFP on a constant and a time trend. This is the method recommended by the FAO, for averaging the disparate changes over the period.
} 


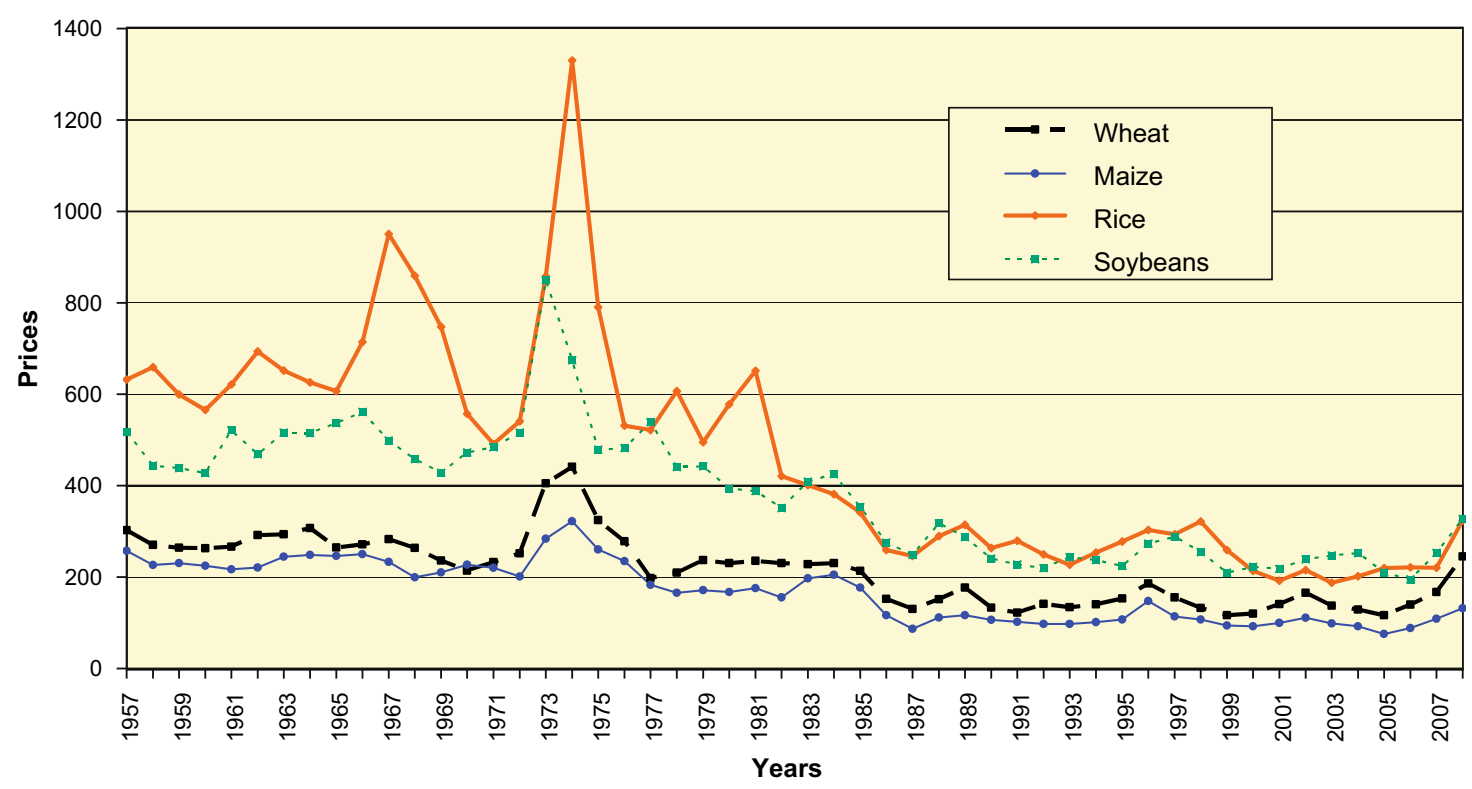

Fig. 1. Constant prices for bulk commodities (1957-2008). Source: FAO internal data.

With no statistically significant fall in the prices of two of the four major grains for 20 years before the $2007 / 2008$ price spike it is odd that the conventional wisdom of falling agricultural prices was not challenged sooner. Correcting this oversight puts the causes of the $2007 / 2008$ price spike in a new light. Why would the price decline have ceased by the late 1980s? The UK cuts in public agricultural R\&D began in 1982 and other developed countries followed, also reducing the funding available to the international system and the developing countries.

Soybeans are different as the crop was growing in importance and the decline starts only in 1990. There were low prices in 2005 and 2006, but if these years are excluded, the growth rate is positive but not significantly different from zero. Again, hardly evidence of an inexorable long run decline. Even for rice prices, which mostly appear to follow the conventional wisdom, the reality is that although rice prices were falling for the last decade, from 1987 there were a dozen years when the growth rate was almost plus $1 \%$, although again insignificantly different from zero according to the statistical tests.

These results are not confined to the four commodities shown above. Other prices are not pictured here, but can be found in the report on which this paper is based (Thirtle and Piesse, 2008). For vegetable oils, soybean oil stood in 2008 at $40 \%$ of its 1974 peak, rapeseed oil at $47 \%$ and palm oil at $41 \%$. Again, the conventional wisdom of falling prices can be quickly demolished. There is no sign of falling prices after 1987 and the last three rows

Table 1

Trends in main grain prices.

\begin{tabular}{lllll}
\hline Crop & Period & Growth rate $(\%)$ & $t$ Statistic & Critical value \\
\hline Wheat & $1987-2006$ & -0.48 & -0.96 & 1.73 (18 dof) \\
Maize & $1987-2006$ & -0.80 & -1.56 & 1.73 \\
Maize & $1987-2007$ & -0.60 & -1.16 & 1.73 \\
Soybeans & $1990-2004$ & +0.14 & +0.27 & 1.76 (13 dof) \\
Rice & $1987-1998$ & +0.94 & +1.06 & 1.81 (10 dof) \\
Soybean oil & $1987-2006$ & +0.60 & +0.38 & 1.73 \\
Rapeseed oil & $1987-2006$ & +1.69 & +2.95 & 1.73 \\
Palm oil & $1987-2006$ & -0.04 & -0.05 & 1.73
\end{tabular}

Critical values are for a one tailed test at the $5 \%$ confidence level. If the null hypothesis allowed for being significantly greater than zero, as well as less than (and the rapeseed result says it should) the critical value is 2.1.

Source: estimates by the authors using FAO internal data. of Table 1 confirm this. The trend for soybean oil and palm oil was not significantly different from zero. For rapeseed oil the decline is not only rejected but the positive growth rate of $1.7 \%$ is significant at the $1 \%$ confidence level. Thus, the only price that did not have a constant long term trend was rising rather than falling and actually rising quite fast.

Thus, when food prices started to rise in late 2006, it was not a sudden reversal, but more a change from stable to rising prices. Dairy products rose first and most sharply, followed by cereals and oilseeds, but meat prices were much less affected and sugar prices were falling. However, food prices did not rise first: they followed commodity prices as oil and metals rose sooner and more sharply. Fertiliser prices followed later and will be discussed below. Now, at the beginning of December 2008, it is clear that the price spikes are past. The FAO Food Price Index has been falling since June, which is when cereals and oils and fats peaked. Dairy products had been falling since November 2007 and sugar and meat started falling from lower peaks by August.

Fig. 2 concentrates on the four major crops, which are wheat, maize, rice and soybeans. It shows that wheat peaked first, in March, followed by rice, which rose later but higher and peaked in May. By June and July maize and soybeans followed. By the end of November wheat stood at $51 \%$ of its peak level, maize at $54 \%$, rice at $61 \%$ and soybeans at $59 \%$. However, wheat was still 19\% above its September 2006 level, maize 31\% above, rice 88\% and soybeans $55 \%$.

Examination of Fig. 1 suggests that this is the normal pattern, in that prices overshoot in the short run and gradually sink back to a long run trend. Thus, the transitory component of the price rise may have worked itself out and in due course the long run trend will become evident. With this decomposition in mind, the next section examines the causes of the price spike and the following section considers the long run forces that will determine the future course of food commodity prices.

\section{Causes of the price spike}

Low stock to utilisation ratios

If a single factor is to be identified as the cause of the recent price spikes, it has to be low stocks. In any model intended to ex- 


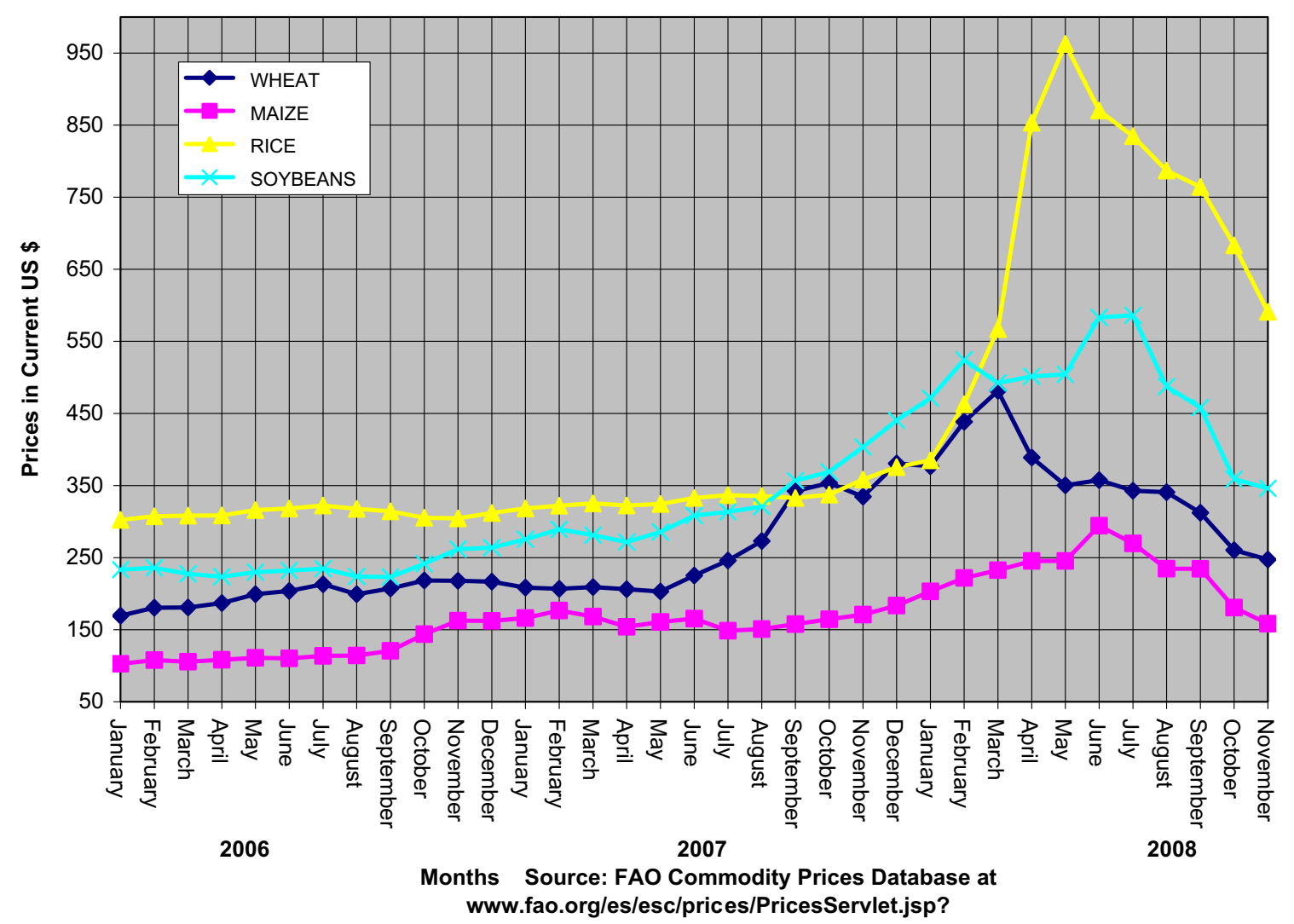

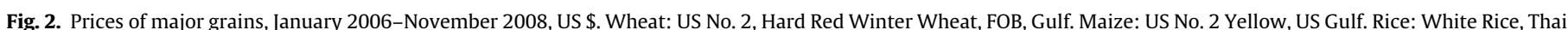
100\% B Second Grade, FOB, Bangkok. Soybeans: US No. 1, Yellow, US Gulf.

plain commodity prices, the stock to utilisation ratio is the key variable. When this is low, there will be upward volatility and indeed, if there are no stocks that can be unloaded to destroy the position of those who speculate on rising prices, then these speculators will be proved right. Thus, low stocks set the scene. Fig. 3 shows the FAO cereals price index against alternative stock/utilisation ratios. It is clear that the two move in opposite directions and this is confirmed by the $r$ value of -0.65 , which would mean a $R^{2}$ of 0.42 in a bivariate regression, or that $42 \%$ of the variance in prices is explained by this one variable.

A longer term view of the stock/use ratio can be found in Trostle (2008), Mitchell (2008a,b) and Abbott et al. (2008), who all plot this ratio as a percentage for a longer period. The point here is that whichever major crops are included, the result is as in Fig. 4. The stock/utilisation ratio for grains and oilseeds was at an all time low of about 15\%, in 1972 and 1973, when the food crisis began

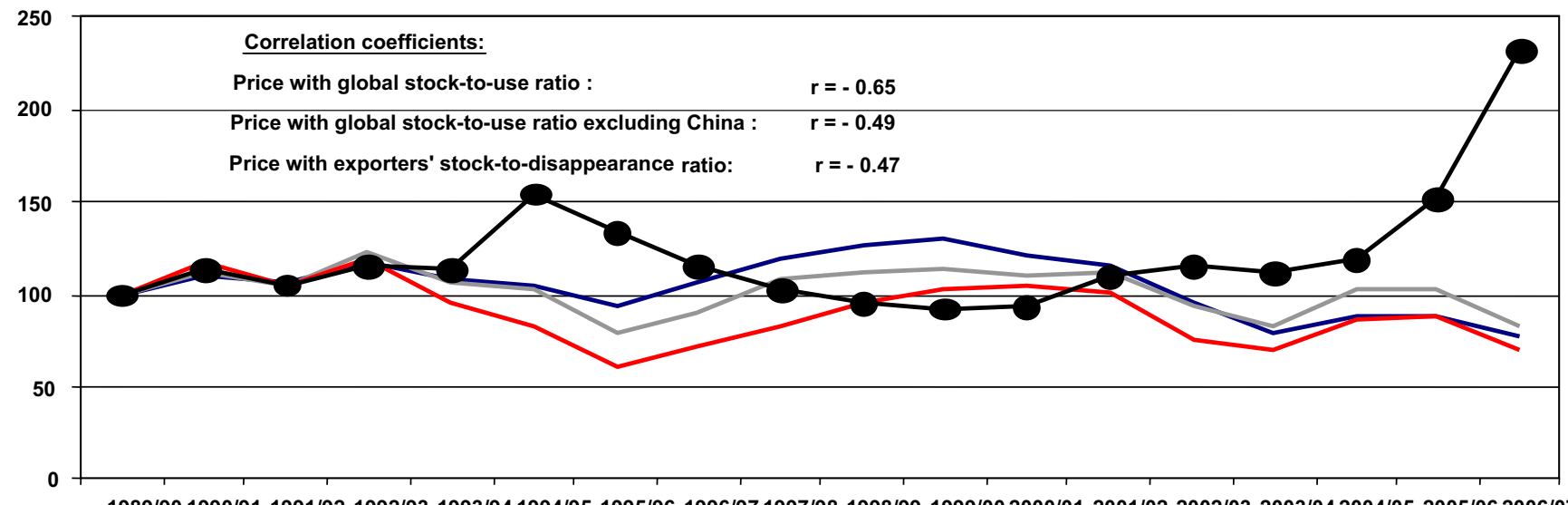

1989/90 1990/91 1991/92 1992/93 1993/94 1994/95 1995/96 1996/971997/98 1998/99 1999/00 2000/01 2001/02 2002/03 2003/04 2004/05 2005/06 2006/07

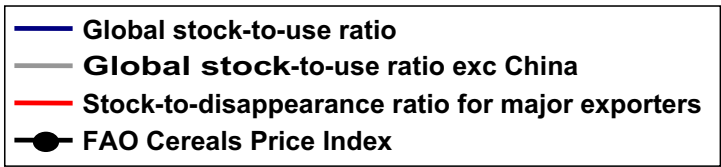

Fig. 3. Relationships between cereal stock ratios and prices. Source: FAO, soaring food prices, (June 2008). 


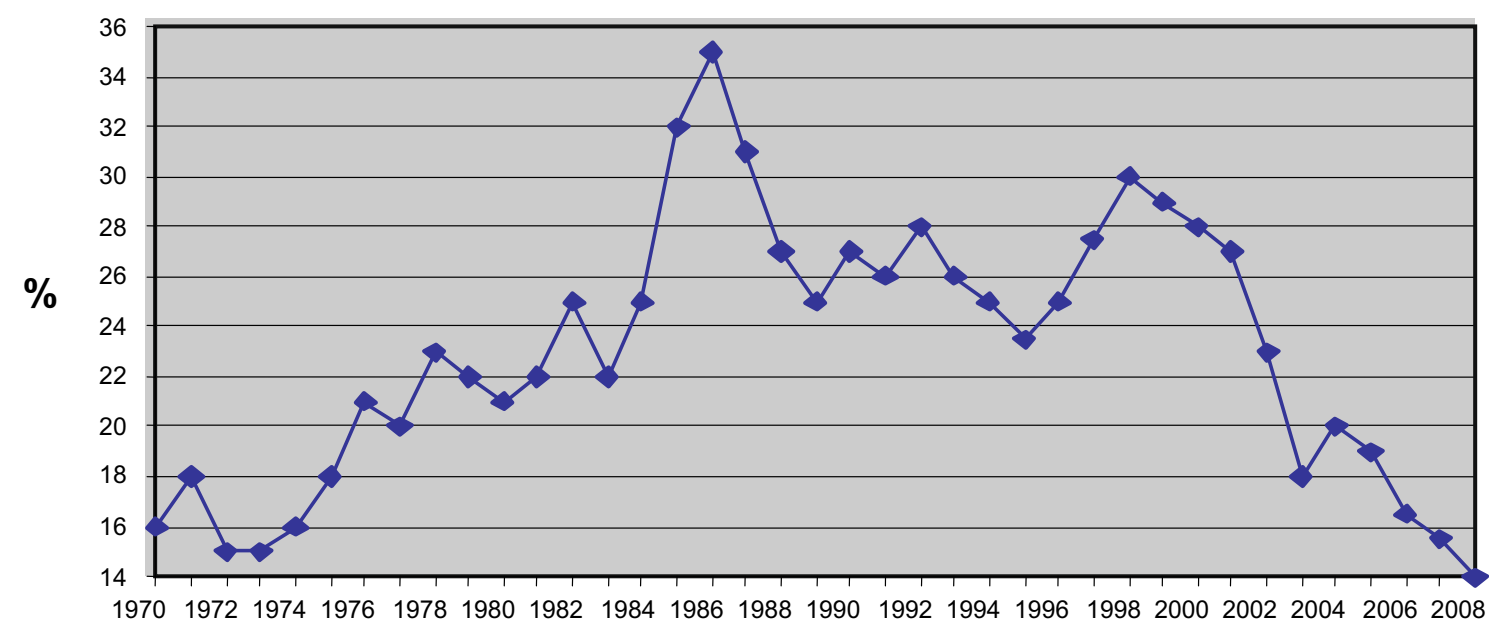

Fig. 4. Long term changes in the stock/use ratio - all grains and oilseeds. Source: adapted from Trostle (2008).

and now, in 2008, it has reached an even lower level of $14 \%$ and prices have again risen sharply. However, see the Data Appendix A, which includes later revisions. It shows that only coarse grains were this low and supports the FAO stance that the stock levels were never as low as the early publications suggested.

However, stocks are a residual, rather than a cause and stock depletion is an outcome of demand exceeding supply. The FAO, GVIEWS, Crop Prospects and Food Situation, 3, July 2008, shows that utilisation has exceeded production in all the years since 1999 , except for 2004, when the harvest was especially good. Their figure suggests that there has been steadily increasing demand and while supply has been increasing it has been affected by weather conditions, giving poor harvests in 2000, 2002 and 2003, which were enough to take stocks to dangerously low levels. ${ }^{3}$ The 2004 harvest was good enough to replenish stocks by about $2 \%$, putting the ratio up to $20 \%$. But then the Australian drought and other weather events led to the very poor harvest of 2006 and the price spike began to take off.

The excellent harvest in 2008 was up $4.9 \%$ on the previous period and is an all time record. This gives some respite as stocks are expected to increase by at least $8 \% .{ }^{4}$ Whilst this is a huge improvement, it is mostly driven by very heavy wheat harvests in Europe. At the other extreme, maize stocks are expected to remain at the same dangerously low levels. Next, we look at the causes of the decline in stocks in more detail, as weather only accounts for the variability. The underlying decline in supply and increase in demand were in fact the result of deliberate policies.

\section{Policy changes to reduce supply and stocks}

For decades the concern of developed country governments has been to reduce the expensive stocks that accumulated because policies to support farm incomes led to over-production. The Common Agricultural Policy produced wheat and butter mountains and wine lakes, while successive US Farm Bills had similar effects. High subsidies and dumping of stocks by the developed countries was seen as extremely damaging to developing country agriculture. This changed in the 1990s as set aside, decoupling of subsidies and production and other environmentally friendly policies intended to reward countryside stewardship instead of output sought to reduce supply.

\footnotetext{
${ }^{3}$ The change in stocks is actually the integral of the difference of production minus utilisation. Just looking at the areas, it is clear that stocks have fallen.

${ }^{4}$ See Appendix A Table 1, which uses the latest estimates and shows an increase of $9.4 \%$.
}

There is another policy reason for supply to be lower than it would have been, which is the prevailing attitudes towards $R \& D$ expenditures in agriculture. In the developed countries, the agricultural surpluses made investments in R\&D unattractive. Why spend money on research which will tend to be output increasing when there is already excessive output? Thus, less technology was available for adaptation by the LDCs and the situation was exacerbated by falling assistance to LDC agriculture and neglect on the part of LDC governments. Thus, technology contributed less to output growth than it would have done. The R\&D issue is considered more fully in the long run factors which follow.

\section{Policy changes to increase demand}

The biggest changes in terms of consequences are the policy initiatives in the US and the EU to promote the use of biofuels. Despite claims that this is a means of reducing carbon emissions, quite clearly (especially in the US) this is also intended to increase energy self sufficiency and support farmers in lieu of subsidies. These policies have succeeded in diverting about one third of the US corn crop to ethanol production and perhaps a similar amount of EU rapeseed to biodiesel. These increases in demand outweigh the supply reductions and together have been all too successful in reducing stocks to far lower levels. The long term consequences of biofuels will be discussed in detail in later sections (especially "Demand side factors: ethanol and biodiesel") as the demand side link between food and energy prices is the most startling outcome to date.

\section{Harvest failures ${ }^{5}$}

The recent past has been marked by several serious droughts that have caused harvest failures such as those in Australia, and floods and typhoons, all of which have reduced world supplies enough to exacerbate the stock shortages caused by deliberate policies. Europe had poor harvests in 2007, which added to the grain and oilseed price increases, as did a poor canola harvest in Canada. However, with the number of countries involved in global food production, some are bound to have below average harvests and some better than average. Mitchell (2008a,b) suggests that those who have identified weather related production shortfalls as a major factor underpinning world cereals prices are being somewhat selective.

Australia, the US, the EU, Canada, Russia and Ukraine had poor harvests (OECD-FAO, 2007). Mitchell (2008a,b, p. 10) says, "The back-to-back droughts in Australia in 2006 and 2007 reduced grain

\footnotetext{
This section is based largely on Mitchell (2008a,b).
} 


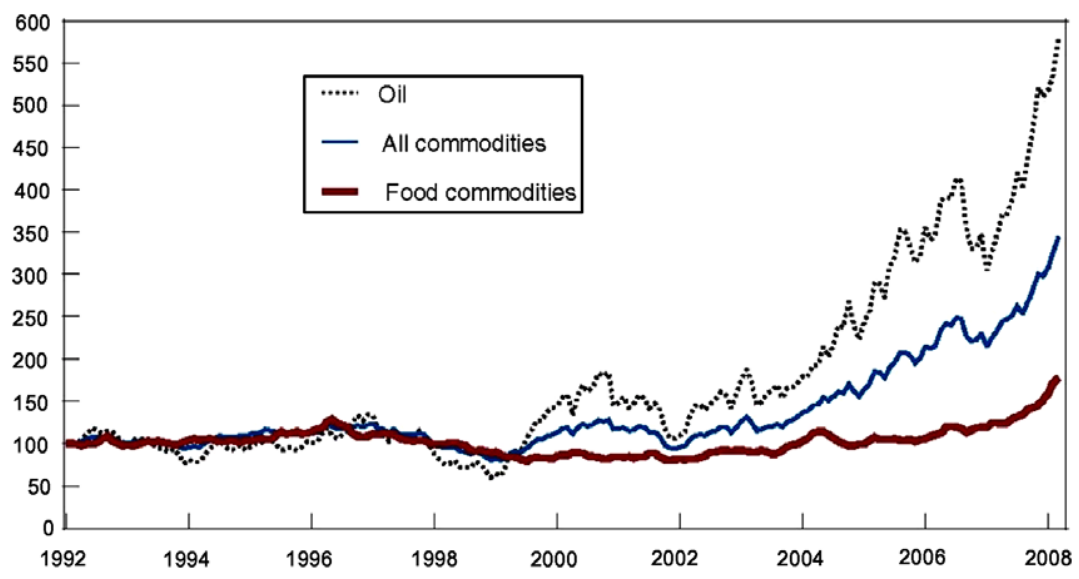

Fig. 5. Indices for oil, commodities and food: $1992=100$. Source: Trostle (2008).

exports by an average of 9.2 million tons per year compared to 2005, and poor crops in the EU and Ukraine reduced their exports by an additional 10 million tons in 2007. However, these declines were more than offset by good harvests in Argentina, Kazakhstan, Russia and the US and 2007 total grain exports from these countries increased by about 22 million tons compared to 2006. Global grain production did decline by $1.3 \%$ in 2006 but it then increased $4.7 \%$ in 2007." Thus, the production shortfall in grains would not have been a major contributor to the increase in grain prices. This shortfall was most significant in wheat, where global production declined $4.5 \%$ in 2006 and then increased only $2 \%$ in 2007 . Global oilseed production rose by $5.4 \%$ in $2006 / 07$ and declined $3.4 \%$ in $2007 / 2008$.

\section{Non-food spot and futures commodity market factors}

These are clearly important and rival low stocks as the root cause of the price spikes in food. Note that whereas in the 1970s crisis food rose first and was followed by other commodities, in the current period prices in the markets for metals and oil rose sooner and faster: food has simply followed, as Fig. 5 shows. The two causes are discussed below.

The first is increases in demand. China reached the turning point in the structural transformation (when the absolute numbers employed in agriculture start to decline) some years ago, despite government attempts to keep workers in the rural areas. India is close to the same point and for both these huge countries that together account for almost half of the world population, there is now very rapid industrialisation and concomitant urbanisation. There are massive building booms in both countries, which have increased the demand for metals (in late July Rio Tinto doubled the price it is charging China for iron ore), other building materials and oil, as power and transport are central to this effort. Thus, real demand from China and India has been driving the boom in nonfood commodity and oil prices.

The second are weak stock and housing markets. The other underlying issues are the uncertainty and weakness of both the stock and housing markets, which have encouraged both speculators and investors to move into the commodity markets. A new development seems to be the amount of long term investment by financial institutions, such as pension funds, that tend to hold stocks (some in the same proportions as the Goldman Sachs commodity index) for a matter of years, as opposed to short term speculators.

Food spot and futures commodity market factors

There have also been changes in the positions and participants in food commodity markets. Again, there are two related factors. The first is speculation and investment.
The poor prospects in stocks, shares and housing make speculation and investment in food commodities an attractive proposition. The low levels of food stocks encourage speculating on price rises. These factors apply to all crops, but whereas there is a speculative bubble for wheat, rice and soybeans, the situation for rice was clearly more of a panic, with countries like the Philippines buying at high prices to ensure sufficient supplies to feed its population. ${ }^{6}$ In rice there was little change in production, consumption or stocks, yet prices doubled from January to August 2008, having been far more stable than the prices of maize and wheat until then. The Data Appendix A shows this stability, as production and supply both increased (by $2.5 \%$ and $0.24 \%$, respectively) and utilisation by $2.2 \%$, but this small deficit is hardly enough to justify a panic. The Table shows that the stock figures for wheat did fall enough to cause reactions, but the rice problem is more the thin international market and the rice export bans, which will be covered in the next section.

The second is export bans and other national policies. The immediate cause of the rice panic was the reaction to fears of price rises, which included export bans. Thus, unfortunate self serving policy responses were a major cause of the problem, but the underlying issue is that rice is a very thin market with only about $7 \%$ of production, or about 30 million tonnes, traded. The extent of the trade restrictions was considerable. By July 2008, half of the 22 Asian countries listed by the FAO (FAO, Crop Prospects and Food Situation, No. 3 July 2008) had export controls and 9 of these were quantity restrictions. These countries include India, Kazakhstan, Pakistan, Ukraine, Russia and Vietnam but also Argentina. Mitchell (2008a,b) says the exports bans, especially by India, led to a steady increase in prices over the following weeks. "While it is not fair to say that all of the price increases were due to the ban, it likely focused attention on the market fundamentals and increased the urgency with which countries bought rice and raised the price expectations of other rice exporters such as Thailand." (Mitchell, 2008a,b).

\section{Decline in the value of the US $\$$}

Beginning in 2002, the US dollar began to depreciate, first against OECD country currencies, and later against many developing countries' currencies. As the dollar loses value relative to the currency of an importing country, it reduces that country's cost of importing. Since the United States is a major exporter of many

\footnotetext{
${ }^{6}$ The Philippines has also passed the turning point in the structural transformation. The rapid progress of structural transformation has itself contributed to upward pressure on oil and non-food commodity and food prices.

7 Based on the account in Abbott, Hurt and Tyner (2008) and alternative views from Gilbert (June 2008a) and Mitchell (2008a,b).
} 
agricultural commodities, especially grains and oilseeds, foreign imports of commodities from the US began to rise.

However, Abbot, Hurt and Tyner (AHT) (2008) have quantified the effect of dollar depreciation and attribute the 2008 price spike predominantly to macro economic phenomena, rather than the real supply to utilisation changes. This approach to the impact of macroeconomic variables on agricultural prices was suggested by Ed Schuh and this paper follows the work in agricultural economics such as Rausser et al. (1986). Using the USDA Economic Research Service agricultural trade-weighted index (USDA RER or USDA ag index) of real foreign currency per unit of deflated dollars, AHT show that from 2002 to 2007 the dollar depreciated $22 \%$, and value of agricultural exports increased 54\%. Grain and oilseed exports increased $63 \%$.

Since 2002 when it peaked, the dollar depreciated 30\% by March 2008 according to the USDA ag index. Against the Euro, the dollar had depreciated 56\% and then another $8 \%$ in April 2008. AHT suggest that half the price spike is attributable to the fall in the US \$. The IMF NEER index, which is an alternative to the USDA index, shows a similar but lower depreciation of $43 \%$ by March $2008 .{ }^{8}$ The objective is to understand nominal dollar commodity price movements and capture the range of variation observed in dollar depreciation. AHT focus on this short period, so inflation is not important. They use the nominal Euro/Dollar exchange rate as the upper bound for the effect of dollar depreciation. This is compared with the USDA ag index and real (deflated) Euros, which are taken to be the lower bound on the impact of supply/utilisation changes, so the difference between the two is used as the estimate of the share of US \$ deflation in the total impact. AHT show that in previous price spikes, all the indices move together, so they attribute these price spikes to real changes in the balance between supply and utilisation.

AHT presents plots of these same three exchange rate indices for corn, soybeans, wheat and rice. For all four crops the nominal dollar index only parts company with the "real" indices in 2004. Since 2002, corn prices in nominal dollars have increased $143 \%$. In real Euros the increase is only 37\%. Furthermore, the prices of corn and other agricultural commodities increased, as happened around 1995-1996, but the three indices move together. From July 1994 to July 1996 , nominal US \$ corn prices increased $105 \%$, and real Euro corn prices increased 94\%. This suggests that the 1995 corn price increases were largely due to supply-utilisation shocks, whereas the current US corn price increases are decidedly different, and are much more closely tied to the weak dollar.

There is little agreement on the impact of the falling dollar. AHT are alone in arguing that it was the dominant factor. Mitchell quotes Baffes (1997) who estimated the elasticity of dollar commodity prices with respect to the dollar exchange rate at between 0.5 and 1.0. The latest estimates from the FAO, used by Sarris (2008), put the elasticity of commodity price with respect to US $\$$ depreciation at between 0.9 for beef to 0.35 for maize, with rice wheat and oilseeds all below 0.5 . Also, the food price changes do not closely correlate with the falling dollar so Mitchell puts the impact at the bottom end of this range. This gives much lower impacts than in ABT. "For example, from January 2002 to December 2004, food prices rose 24\% and the dollar fell 34\% against the Euro. Then, from January 2005 to December 2007, food prices rose 65\% and the dollar fell 10\% against the Euro." (Mitchell, 2008a, p. 11). Thus, the US \$ was less weak when food price increases were at a peak. However, ABT point out that stocks need to be reduced first in food crops, so effects are lagged and do not match the dollar value changes.

\footnotetext{
8 The USDA and IMF indices are for the dollar exchange rate relative to a basket of currencies, which avoids results being determined by particular one country events.
}

Over the entire period of food price increases from January 2002 until February 2008, the US \$ fell $40 \%$ against the Euro and food prices rose $140 \%$. "So, perhaps $20 \%$ of the rise in food prices over the entire period was due to dollar weakness" (Mitchell, 2008a, p. 11). Speculative activity also increased and is tied to the declining dollar and this must have increased food prices. This increased activity is indicated by the quadrupling of wheat futures contacts with the Chicago Board of Trade.

Mitchell says the impact on prices is hard to quantify and most academics still doubt that such activity changes prices from the levels which would have prevailed otherwise (Gilbert, 2008b). Gilbert argues that the depreciation of the dollar has not been sufficiently large or general to be a major explanatory factor. The US \$ has fallen by $25 \%$ relative to the Euro since 2005 and hardly at all relative to some currencies, especially some key Asian ones.

The level of disagreement on this issue is indicative of how much difference the way economic changes are measured can make. There are relationships between the price of commodities, especially oil, the value of the US $\$$ and food prices, which are not well understood. There is no doubt that when the oil price began its swift decline from July 2008, the prices of all the major food commodities led or followed. However, the proportion of the price spike in oil or food caused by US \$ depreciation remains an area of contention.

\section{A brief summary of the price spike}

- Market adjustments in commodities that involve stocks are usually expected to overshoot the long run equilibrium price and slowly fall back towards it as the attractions of speculation fade. The seven causes above are mostly somewhat transitory.

- Rather too late, developed country governments are now encouraging production, instead of trying to reduce it. Biofuel policies are being questioned and are likely to be adjusted. Harvests in 2008/2009 are very good, partly due to policy induced supply responses that have increased supply and lowered prices, but it is unlikely that stocks can be rebuilt quickly. See Data Appendix A for the modest increases in stock levels that have resulted from the excellent harvest.

- Export bans are being removed as the climate improves and these and other beggar-thy-neighbour policies prove to be expensive and unnecessary.

- The conditions in the non-food commodity markets can be expected to change too and the economic downturn has reduced the oil price to below $\$ 50$ per barrel, which seemed unthinkable when it was at almost $\$ 150$ in July.

- The extent of the price falls is not yet clear, but wheat and maize prices have fallen $50 \%$ from their peak levels, rice by $40 \%$ and other crops are following suit. This suggests that at least half of the price spike was the result of short term forces: a speculative bubble in the case of wheat, maize and soybeans and a panic in the case of rice.

\section{Long run changes that will determine the future course of prices}

Having dismissed the long run tendencies in the world economy as immediate causes of high food prices due to their gradual nature being at odds with sudden rapid changes, this does not mean that the long run forces are less important. In fact, they are likely to prove dominant once the bubbles and panics subside and prices settle again at prices that are expected to be some $40 \%$ above the pre 2006 levels, according to OECD/FAO May, June and September and November (2008). 
$(2000=100)$

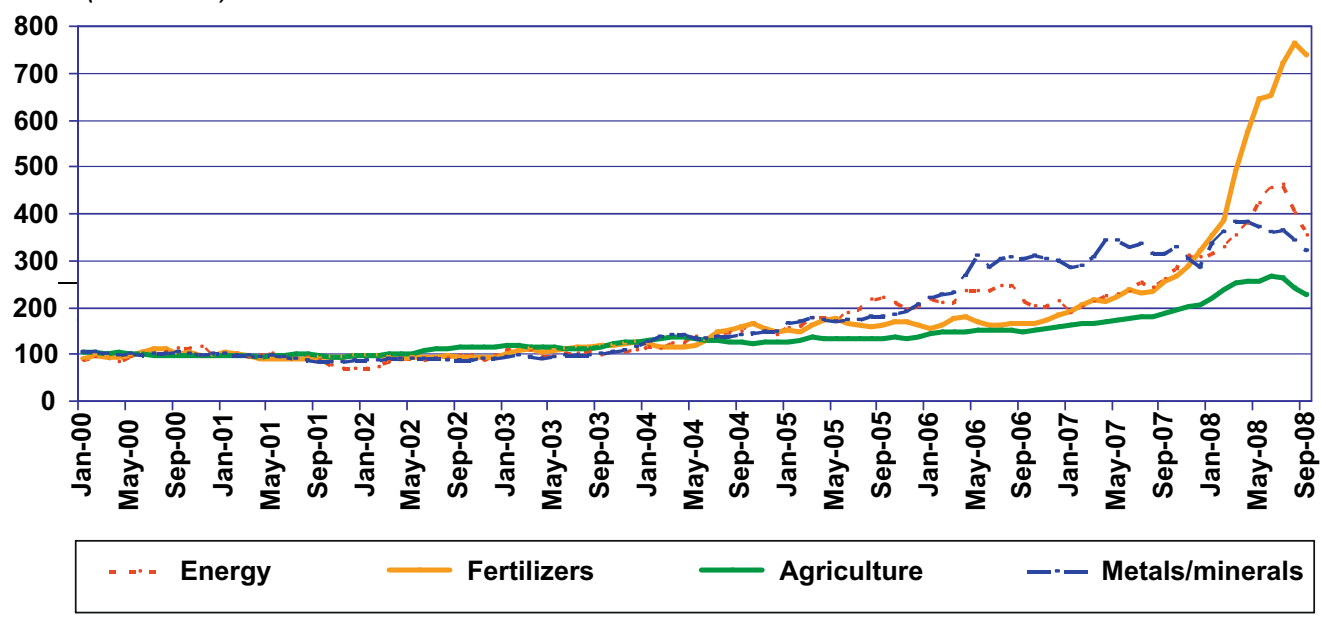

Fig. 6. Fertiliser price, relative to energy, metals and agricultural prices. Source: Haniotis (2008).

\section{Supply side factors: prices of fertiliser and fuel ${ }^{9}$}

Agriculture has always been strongly linked to the oil price on the supply side because inputs of fertiliser and fuel are a substantial share of total costs in developed country agriculture. In 1973, US farm prices hit an all time high at the same time as the OPEC oil price spike. Artificial nitrogen fertiliser uses large amounts of fuel to produce, so it is not surprising that fertiliser prices respond in this way. In the current situation this position has been exacerbated by a world-wide lack of production capacity, so fertiliser prices have risen even more than oil prices. This will be reflected in food prices and the cost of fuel on the farm and for transporting and processing food products. The impact of fertiliser prices has not attracted the attention it warrants. In developing countries, it will have serious impacts on the ability of smallholders to maintain the gains they have made. ${ }^{10}$ In developed countries it will be exacerbated by the cost of fuel on the farm and by increased costs of transporting food items.

The price of nitrogen (urea) has quadrupled since 2000, a bigger rise than for cereals, which increased in price by a factor of 2.8 over the same period. Phosphates (TSP) did not increase substantially until 2007, but prices have increased to over five times the base level and potash to three times. Phosphates and potash are basically products of the mining industry and are linked in with the other mined commodities such as metal ores. Fig. 6 shows the extent of the rise in fertiliser prices relative to energy, metals and agricultural prices. This much of an increase suggests that fertiliser prices must have been in part responsible for the recent price spike, but the question is how much. Mitchell, (2008a, p. 4) has calculated the impact of the fertiliser and fuel price rises on US production costs, which he says have contributed about $15 \%$ to higher US food crop production costs. ${ }^{11}$

Mitchell (2008a,b) says, "This has occurred directly through the increased cost of producing grains and other crops (to fuel machinery, power irrigation systems, and dry and transport grain) and indirectly because energy is a major input into fertiliser and agricultural chemicals production and these are essential inputs into food crop production. The combined energy, chemical and fertiliser costs accounted for $16 \%$ of US soybean production costs, $27 \%$ of US

\footnotetext{
9 This section draws heavily on Mitchell (2008a,b).

10 See for instance http://www.future-agricultures.org , Briefing, The Global Fertiliser Crisis and Africa, June 2008.

11 Note that this really is a calculation that allows a sensible estimate, unlike many other causes for which only guesses can be made.
}

wheat production costs, and $34 \%$ of US maize production costs in 2007 according to the USDA and these costs increased by an average of $50 \%$ from 2000 to 2007 and contributed about $15 \%$ to production costs. Since the US accounts for $40 \%$ of global grain exports and one-quarter of the global oilseeds exports, these costs were quickly reflected in global food prices."

Energy prices have now fallen, but fertiliser prices remain very high and this will reduce supply response in the coming year. The farmer's input decision is based on the price of the output divided by the price of fertiliser and now that crop prices have fallen UK wheat farmers will not be inclined to use so much fertiliser and yields will reflect this.

\section{Supply side factors: Lack of investment in agricultural $R E D^{12}$}

Agriculture has not been prospering in the UK and this tends to mean delaying investment expenditures. This has been true in many other countries and consequently the supply response to higher prices will be less and slower. This is because both expansion of the area planted and productivity growth will be less than they might have been.

The longer term response depends on the availability of appropriate technology. In the UK the level of expenditures in agricultural R\&D ceased growing in 1982 and total factor productivity (aggregate output per appropriately weighted aggregate of inputs) ceased growing from 1984, having grown at about $2 \%$ per annum since 1953 . Yield growth similarly fell from about $2 \%$ to $0.2 \%$, so only labour productivity continued to increase. The cuts in public expenditures did not lead to compensating increases in private R\&D investment. Instead, patent counts declined, following the trend in public R\&D expenditures (Thirtle et al., 1997, 2004). This development is not confined to the UK. Much the same occurred in most other developed countries (Alston et al., 1999). In all areas, the rate of growth of agricultural R\&D expenditures has been in decline since data collection began in 1976. Public R\&D expenditures for the high income countries fell from 10,534 million constant 2000 international US \$ in 1991 to10,191 million in 2000 (Pardey et al., 2006). This small fall is minor, but R\&D was also retargeted away from productivity and towards public interest issues such as the environment, animal welfare and food safety. Thus, the allocation to productivity enhancing research declined substantially

12 This section draws on work done at IFPRI, especially Rosegrant (2008). 


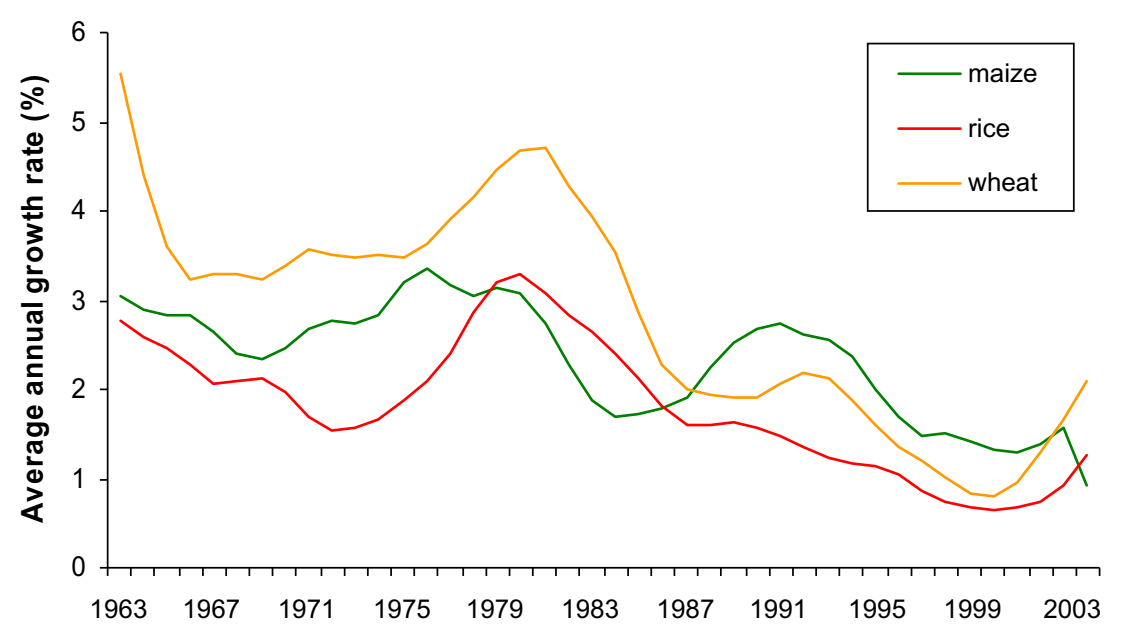

Fig. 7. World productivity growth rates for major cereals. Source: World Development Report, 2008, World Bank, Washington, DC.

(Alston et al., 1999), but the extent of this redirection of funds remains unquantified.

The neglect of agricultural research has had a clear impact on agriculture at a world level. The simplest measure is yields and the expectation is of yield growth. Fig. 7 shows that for the most important cereal crops the growth rates were $3 \%$ or better at the height of the green revolution in the early 1980s. Since then the growth rates have fallen so that by 2000 , the rates for rice and wheat were about $1 \%$ and maize a little better at around $1.5 \%$. There seems to be a slight recovery since 2000 , which is surely needed as these growth rates are less than population growth and per capita food availability would be falling.

The problems of low R\&D expenditures and slowing productivity growth are closely linked to the prices of oil, fuel and fertiliser, discussed above. The dominant forces in agriculture in the developed countries in the 20th century were the fertiliser revolution and the mechanical revolution. Thus, it is a fair generalisation to say that almost all the agricultural technologies available are energy intensive. If energy is to remain expensive, they are not appropriate, but it is hard to see energy-efficient alternatives.

How can yield growth be maintained with lower energy inputs, if artificial nitrogen becomes increasingly expensive? How can agriculture reduce the pollution it causes, manage with less irrigation water, produce less methane and less nitrogen runoff? There are some exceptions that head in the right direction, one of which must be better targeting. ${ }^{13}$ Satellite technology is now used to determine exactly the inputs needed in advanced country farming. In poor countries, drip irrigation (which is labour intensive) increases employment and saves scarce water. Fertiliser and pesticide can be targeted at individual plants. This was done in sugar beet in the 1990s (Thirtle, 1999) when pelleting of seeds allowed each one to be encapsulated with its own supply of plant protection chemicals and fertiliser. This reduces input use and pollution impressively and the same approach is spreading to LDCs with similar targeting of individual plants with their own input doses, by using new ideas like small briquettes of urea. Using new technologies to improve old techniques is also productive. In KwaZulu Natal, South Africa, genetically modified herbicide tolerant white maize is being used in minimum tillage systems. Roundup herbicide is used to kill the weeds so there is no deep ploughing, which rehabilitates the oxen, which are used for shallow ploughing

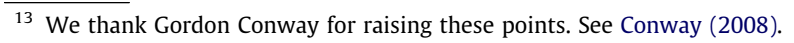

for planting and this cuts soil erosion substantially (Gouse et al., 2006).

Supply side factors: climate change $e^{14}$

The effect of this other very long run factor is unclear, but higher temperatures in the tropics and more variability will result in more poorer harvests, often in the most vulnerable and poorest countries of SSA. The recent country level estimates by Cline (2007) show agricultural production reduced by over $25 \%$ in the worst affected tropical countries, while there are gains of a similar magnitude in some temperate countries and regions, such as New Zealand, parts of North America and in northern Europe. The agricultural losses are correlated with increased droughts and variability across much of the tropics, again with reduced problems in the northern regions. The droughts, of course, are a factor in the scarcity of water for irrigation, which is expected to become less reliable in all regions except Latin America.

\section{Demand side factors: population and Income growth}

It has been suggested that the rapid rise in incomes in China and India is the main cause of the current food price spikes (von Braun, 2008), but this direct effect is unlikely. The dominant causality runs instead from the increased demands for metals and oil, to food by way of the increases in the oil price and possibly through all the macroeconomic inter-linkages that surround US \$ price changes. Income growth is gradual and the price spike was quite sudden. Also, both countries were exporting small amounts of most food commodities, with the exception of China's import of 35 million tonnes of soybeans from the US in 2007. It is true that at higher incomes people eat more dairy products and white and red meat. It takes roughly three times as much land to provide the same amount of calories with dairy or white meat as it does with grain, because animals are inefficient calorie factories and for red meat the factor can be at least times seven. ${ }^{15}$ However, red meat prices have risen much less than grains and dairy prices have now fallen. Now, meat prices must rise as feed prices have risen, but this is clearly a secondary effect.

\footnotetext{
14 This section is largely from Rosegrant (2008).

15 Haniotis (2008) shows that the feed demand generated by increased meat consumption would easily have been met by increased production, were it not for the diversion of maize into ethanol.
} 
We now look at these demand changes in more detail, beginning with income growth. The annual growth rates of GDP for East Asia and the Pacific region, have exceeded 8\% since 2003. South Asia, by 2005 , had reached a similar growth rate. These two regions account for a large proportion of world population, so the growth of demand generated is huge. Even Sub-Saharan Africa, which has performed poorly, was approaching 6\% annual GDP growth by 2005 , so the whole of the world economy was experiencing an unusually widely distributed boom.

Both China and India are usually net exporters of cereals, but as their utilisation has slowly increased the level of their exports has tended to diminish. Mitchell argues that income growth in developing countries was not a major factor responsible for the large grain price increases. It has contributed to increased oilseed demand, especially China's purchase of 35 million tonnes of soybeans in 2007, which increased oilseed prices as China imported for its livestock and poultry industry. We also noted that India's ban on rice exports was a major cause of the rice price panic. But, these are single events. The increase in global consumption of wheat grew by only $0.8 \%$ and rice by $1.0 \%$ per annum, from 2000 to 2007 . Maize demand grew by $2.1 \%$ (excluding the demand for biofuels in the US). This was slower than demand growth during 1995-2000 when wheat, rice and maize demand increasing by $1.4 \%, 1.4 \%$ and $2.6 \%$ per annum, respectively (FAO, Crop Prospects and Food Situation, 2008).

\section{Demand side factors: ethanol and biodiesel}

Although we have tended to argue that low stock/utilisation ratios, leading to speculation and all the macroeconomic effects surrounding the falling dollar are the main causes of the price rises and that they are in large part a bubble, the most far reaching change has been saved until last. Ethanol demand is a new phenomenon that has transformed the food markets and it will not now go away. Whereas food prices were previously linked to oil prices only on the supply side, at oil prices above about $\$ 55$ per barrel, corn is used to make ethanol to mix with petrol.

Mitchell (2008a,b) considers that the US demand for maize to produce ethanol is the single greatest cause of the price rises. Ethanol demand was sufficient to use up all the extra production from 2004, so all other consumption increases reduced stocks. Global maize production rose 55 million tons to 2007 and biofuel use in the US increased by 50 million tons. Mitchell says, "Global consumption for all other uses increased 33 million tons, which caused global stocks to decline by 27 million tons and maize prices to more than double." Thus, it is biofuel use that has tipped the balance, accounting for at least $25 \%$ of US production by $2007 / 2008$ and $11 \%$ of global output. The increasing share of ethanol in maize utilisation has continued so that it now accounts for almost one third of US production. This same effect has occurred in vegetable oils, with about $7 \%{ }^{16}(9 \mathrm{mt}$ out of $132 \mathrm{mt}$ ) of world output going into biodiesel production in 2007. Mitchell's figures show that one third of the increase in vegetable oil use from 2004 to 2007 has been due to biodiesel. Mitchell gives figures for the subsidies and mandates that have encouraged biofuel demand and argues that while oil prices may well settle above the level at which ethanol demand would continue without policy measures this is not true of biodiesel, because the additional demand has led to such large increases in rapeseed prices.

\footnotetext{
16 However, maize us for ethanol leave a residual known as distillers grains, which is used for feed, so one third of the crop going to ethanol reduces feed availability by
} about one quarter rather than one third (Renewable Fuels Association, 2008)
This market for maize is expected to keep growing and the energy market is huge, so it literally means at some floor price, maize prices are supported by a perfectly elastic demand from the energy industry. The floor prices needed to ensure continued energy use of different feed stocks vary, with Brazilian sugar cane economical at as low as $\$ 35$ US per barrel. For maize it is about $\$ 55$, but for biodiesel to be economical the oil price needs to be about $\$ 80$ (Schmidhuber, 2006). The exact magnitudes depend on the prices of oil and its substitutes, such as maize, the price of ethanol and the efficiency of the conversion process. There is also a choke price, as with oil at $\$ 140$ per barrel and maize at $\$ 7$ per bushel, some ethanol plants were lying idle. Thus, Chris Hurt, agricultural economist at Purdue University, says that the price of a barrel of oil is about 20 times the price of a bushel of corn. Alternatively, a tonne of maize should cost at least twice the price of a barrel of oil.

Mitchell (2008a,b) presents evidence of land substitution between maize, soybeans and wheat, so these three major crop prices will move together (although it is not known how perfect the price transmission is). Then, maize is also the main animal and chicken feed, so meat and dairy prices will also move with maize. Of the major commodities, the linkages are weak only for rice and sugar, so the oil price will literally put a floor under agricultural prices in the trading nations. This link through competition for land is part of the explanation of the way prices have moved since 2006. More maize and oilseeds for biofuels reduced plantings of other crops and contributed to price increases in crops such as wheat (the Data Appendix A suggest substitution). In 2007/2008 there was a $23 \%$ increase in US maize plantings and a $16 \%$ decline in soybean area, which combined with the big Chinese purchase, pushed up oilseed prices. The decline in soybean area led to a $19 \%$ decline in production and a $75 \%$ decline in US end of year stocks and directly contributed to the $80 \%$ increase in soybean prices from 2007 to 2008. Cropland in major US field crops only increased $2.5 \%$ in 2007 , so the wheat area was static and US wheat stocks fell by half in the 2007/2008 crop year to the lowest level in 60 years according to the USDA. Then prices more than doubled in the 10 months from April 2007 to February 2008.

The result of this market development is that the long decline of agricultural prices is over, unless oil prices stay below $\$ 55$, which is not the long run expectation. The OEDC/FAO Agricultural Outlook simply says prices will settle at about $40 \%$ above their 2006 levels and for the next harvest it is input prices that will keep them up, regardless of the oil price.

\section{Conclusion}

The FAO (Food Outlook, November 2008) is keen to point out that the food price problem is not over. The stock to use ratio has improved, but mostly for wheat, and is still at its second lowest level for three decades, so rebuilding will take several more good harvests (see the Data Appendix A). Maize stocks have improved very little this year and remain dangerously low. However, it is hard to foresee an immediate crisis with a world-wide recession to reduce demand for both food and oil and with the oil price dipping below $\$ 50$. This may not be a solution, but gives some respite and a chance to avert a future crisis. A real recovery should be supply led, so it is crucial that governments act now to secure the future.

The FAO point out that while the developing country consumers are the obvious losers in the food price crisis, producers are not benefiting from the higher prices due to poor output price transmission and higher input costs. As a result their supply response has been poor so far and may well get worse. Fertiliser prices will 
fall now that oil prices have fallen, but the lags will probably mean very expensive inputs for the coming year, which will reduce the response in all countries. The financial crisis is bound to exacerbate this situation, as it will affect the availability of credit and without modern inputs output will be constrained.

The long term expectation is that oil prices will only be low for the duration of the recession, so action is needed now to improve the state of world agriculture before then. If agriculture is to provide both sufficient food and energy in the future, its prospects are exciting, but many of the responses needed operate only with long lags. Thus, agricultural R\&D investments, appropriate institutional changes to provide incentives and infrastructure improvements are needed now. The problem is not solved, it is merely delayed.

\section{Appendix A \\ Data Appendix. Basic data on world cereal situation (million tonnes)}

\section{References}

Abbott, P.C., Hurt, C., Tyler, W.E., 2008. What's Driving Food Prices? Issue Report 75, Farm Foundation, Oak Brook, Illinois.

Alston, J., Pardey, P., Smith, V., 1999. Paying for Agricultural Productivity. Johns Hopkins University Press, Baltimore.

Baffes, John, 1997. Explaining stationary variable with non-stationary regressors. Applied Economics Letters (4), 69-75.

Cline, W.R., 2007. Global Warming and Agriculture: Impact Estimates by Country. Peterson Institute. ISBN: 0881324035, 9780881324037.

Conway, G., 2008. Confronting the Global Agricultural Crisis of the 21st Century. Presentation, World Food Prize, Des Moines, Iowa, October.

FAO, 2008. Soaring Food Prices: Facts, Perspectives, Impacts and Actions Required High-Level Conference on World Food Security: The Challenges of Climate Change and Bioenergy. Rome, June.

FAO, 2008. FAO's Initiative on Soaring Food Prices Guide for Immediate Country Level Action. Second Draft, May.

FAO, 2008. Hunger on the Rise: Soaring Prices Add 75 Million People to Global Hunger Rolls. FAO Briefing Paper Rome: FAO, September. <http://www.fao.org/ newsroom/common/ecg/1000923/en/hungerfigs.pdf>.

FAO, 2008. Food Outlook: Global Market Analysis, November.

FAO, 2008. Global Information and Early Warning System GVIEWS, Crop Prospects and Food Situation, February, July and October. Global Cereal Supply and Demand Brief.

FAO, 2008. GVIEWS Crop Prospects and Food Situation, November.

\begin{tabular}{|c|c|c|c|c|c|c|}
\hline & $\begin{array}{l}2005 / \\
06\end{array}$ & $\begin{array}{l}2006 / \\
07\end{array}$ & $\begin{array}{l}2007 / \\
08\end{array}$ & $\begin{array}{l}\text { Forecast 2008/ } \\
2009\end{array}$ & $\begin{array}{l}\text { Change: } 2007 / 2008 \text { over } 2006 / \\
2007(\%)\end{array}$ & $\begin{array}{l}\text { Change: } 2008 / 2009 \text { over } 2008 / \\
2007(\%)\end{array}$ \\
\hline Production $^{\mathbf{a}}$ & 1003 & 2011 & 2128 & 2241 & 5.85 & 5.32 \\
\hline Wheat & 626.7 & 597 & 611 & 677 & 2.33 & 10.89 \\
\hline Rice (milled) & 424.3 & 429 & 440 & 450 & 2.52 & 2.43 \\
\hline Soybeans & 221 & 236 & 221 & 238 & -6.49 & 7.89 \\
\hline Supply ${ }^{\mathbf{b}}$ & 2524 & 2484 & 2530 & 2665 & 1.87 & 5.32 \\
\hline Rice & 523.7 & 532.7 & 534.0 & 558 & 0.24 & 4.49 \\
\hline Utilisation & 1001 & 2062 & 2126 & 2197 & 3.11 & 3.33 \\
\hline Wheat & 620.1 & 619 & 616 & 643 & -0.55 & 4.47 \\
\hline Coarse grains & 1001 & 1016 & 1074 & 1109 & 5.72 & 3.31 \\
\hline Rice & 419.8 & 427 & 437 & 444 & 2.20 & 1.81 \\
\hline $\begin{array}{l}\text { End of season } \\
\text { stocks }\end{array}$ & 473 & 426 & 433 & 474 & 1.62 & 9.42 \\
\hline Wheat & 182.8 & 160 & 155 & 187 & -3.00 & 20.31 \\
\hline - Main exporters ${ }^{\mathrm{e}}$ & 59.8 & 37 & 27 & 43 & -26.50 & 58.74 \\
\hline Coarse grains & 185.3 & 162 & 169 & 172 & 4.33 & 1.90 \\
\hline - Main exporters ${ }^{\mathrm{e}}$ & 90.6 & 62.2 & 71 & 62 & 14.47 & -13.62 \\
\hline Rice & 104.6 & 104.6 & 109.3 & 115.4 & 4.49 & 5.58 \\
\hline - Main exporters ${ }^{\mathrm{e}}$ & 22.9 & 23.5 & 25.8 & 28.7 & 9.79 & 11.24 \\
\hline \multicolumn{7}{|c|}{ World stock to use ratio } \\
\hline Wheat & 29 & 26 & 24 & 30 & -7.31 & 22.41 \\
\hline Coarse grains & 18 & 15 & 15 & 16 & 0.66 & 4.61 \\
\hline Rice & 25 & 24 & 25 & 26 & 2.50 & 3.66 \\
\hline
\end{tabular}

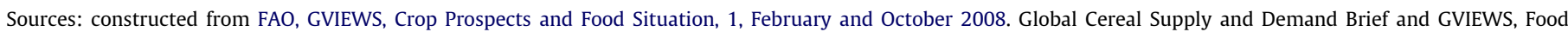
Outlook, Global Market Analysis, November 2008.

a Data refer to calendar year of the first year shown. Totals are for cereals, not including soybeans.

b Production plus opening stocks.

c For wheat and coarse grains, trade refers to exports based on July/June marketing season. For rice, trade refers to exports based on the calendar year of the second year shown.

d May not equal the difference between supply and utilisation because of differences in individual country marketing years.

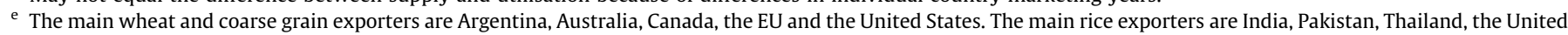
States and Viet Nam. 
FAO, 2008. Food and Agriculture Organization of the United Nations. FAOSTAT Database. <http://faostat.fao.org>.

Gilbert, Christopher L., 2008a. How Should Governments React to High Food Prices? June.

Gilbert, C.L., 2008b. Commodity Speculation and Commodity Investment Department of Economics, University of Trento, Italy.

Gouse, M., Piesse, J., Thirtle, C., 2006. Output and labour effects of GM maize and minimum tillage in a communal area of KwaZulu Natal. Journal of Development Perspectives (2), 35-48.

Haniotis, Tassos, 2008. The 2008 "food crisis": what lessons? Paper Presented at a Conference on "The Food Crisis" of 2008: Lessons for the Future" Held at Imperial College, Wye Campus, London, October 28.

Mitchell, Donald, 2008a. A Note on Rising Food Prices, World Bank, April.

Mitchell, D., 2008b. A Note on Rising Food Prices. Policy Research Working Paper \#4682. World Bank, Development Prospects Group, Washington, DC.

OECD-FAO, 2007. Agricultural Outlook 2007-2016. <http://www.oecd.org/ dataoecd/6/10/38893266.pdf>.

Pardey, P., Beintema, N., Dehmer, S., Wood, S. 2006. Agricultural Research A Growing Global Divide? IFPRI, May.

Rausser, Gordon, James, Chalfant, Alan, Love, Kostas, Stamoulis, 1986. Macroeconomic linkages, taxes and subsidies in the US agricultural sector. American Journal of Agricultural Economics 68, 399-412.

Renewable Fuels Association, 2008. Understanding Land Use Change and US Ethanol Expansion. Washington, DC.

Rosegrant, M., 2008. Implications of Rising Food Prices for Agricultural and Rural Development Issues, Keynote Presentation Given to the Annual Meeting of the Sustainable Development Network. The World Bank, Washington DC, February 21.
Sarris, A., 2008. Agricultural Commodity Markets and Trade: Price Spikes or Trends? Paper Presented at a Conference on "The Food Crisis" of 2008: Lessons for the Future" Held at Imperial College, Wye Campus, London, October 28.

Schmidhuber, Josef, 2006. Impact of an increased biomass use on agricultural markets, prices and food security: a longer-term perspective. In: Paper for an International Symposium of Notre Europe, Paris, November.

Thirtle, C., 1999. Producer funding of R\&D: productivity and the returns to R\&D in British Sugar, 1954-1993. Journal of Agricultural Economics 50, 450-467.

Thirtle, C., Lin, L., Holding, J., Jenkins, L., 2004. Explaining the decline in UK agricultural productivity growth. Journal of Agricultural Economics 55 (2), 343366 (July).

Thirtle, C., Palladino, P., Piesse, J., 1997. On the organisation of agricultural research in Great Britain, 1945-1994: a quantitative description and appraisal of recent reforms. Research Policy 26(December), 557-576.

Thirtle, C., Piesse, J., 2008. An Explanatory Review of the World Food Commodity Price Events of 2007-2008. A Report to the Chief Scientific Advisor. Department for Innovation, Universities and Skills, London.

Trostle, R., 2008. Global Agricultural Supply and Demand: Factors Contributing to the Recent Increase in Food Commodity Prices. Economic Research Service Report WRS-0801. United States Department of Agriculture, Washington, DC, July (revised).

von Braun, Joachim, 2008. High rising food prices: why, who is affected how, and what should be done? In: USAID Conference: Addressing the Challenges of a Changing World Food Situation: Preventing Crisis and Leveraging Opportunity, Washington DC, April 11.

World Bank, 2008. Agriculture for Development. World Development Report 2008 World Bank, Washington, DC. 